\begin{tabular}{|ll|}
\hline Received & $: 9$ December 2019 \\
Revised & $: 31$ January 2020 \\
Accepted & $: 3$ February 2020 \\
Published & $: 4$ February 2020 \\
\hline
\end{tabular}

\title{
Directive Speech Acts in Indonesian Language Learning in Surakarta Citizens' High Schools
}

\author{
Siprianus Nahak ${ }^{1, a)}$, Sarwiji Suwandi ${ }^{1}$, Nugraheni Eko Wardani ${ }^{1}$ \\ Pascasarjana Pendidikan Bahasa Indonesia, Universitas Sebelas Maret, Indonesia \\ E-mail: ${ }^{\text {a) }}$ siprianusnahak@ gmail.com
}

\begin{abstract}
The directive speech act in learning is speech act concerned on the conversation context. Conversation context aimed includes with whom, to whom, what, and how the speech delivered, therefore it mush be concerned by teacher and student in learning process. This research is conducted to describe directive speech act and between teacher with student and student with student in Indonesian learning at Surakarta Citizens' High Schools. The purpose of this research is to know the directive speech act in Indonesian learning process. The method conducted of this research is qualitative descriptive. The object of this research includes speech between teacher with student and student with student involved in Indonesian learning process. The data collecting technique of this research is conducted by: observation, recording, and note. The data analysis of this research is describing the recording value, data reduction, data interpretation, and summarising. Based on research value at Surakarta Citizens' High Schools, shows that directive speech act conducted by the teacher with student more dominant is done by teacher. It happens because the teacher as good figure of speaking and polite in speech.
\end{abstract}

Keywords: directive speech act, Indonesian learning

\begin{abstract}
Abstrak
Tindak tutur direktif dalam pembelajaran merupakan tindak berbahasa yang memperhatikan konteks pembicaraan. Konteks pembicaraan yang dimaksud berkaitan dengan siapa, kepada siapa, apa, dan bagaimana tuturan itu disampaikan oleh karena itu, menjadi perhatian untuk guru dan siswa dalam proses pembelajaran. Penelitian ini dilakukan untuk mendeskripsikan tindak tutur direktif antara guru dengan siswa dan siswa dengan siswa dalam pembelajaran Bahasa Indonesia di SMA Warga Surakarta. Tujuan dalam penelitian ini untuk mengetahui tindak tutur direktif dalam proses pembelajaran Bahasa Indonesia. Metode yang digunakan dalam penelitian ini adalah dekriptif kualitatif. Objek dalam penelitian ini mencakup tuturan antara guru dengan siswa dan siswa dengan siswa. Subjek dalam penelitian ini adalah guru dan siswa yang terlibat dalam proses pembelajaran bahasa Indonesia. Teknik pengumpulan data dalam penelitian ini dilakukan dengan cara: pengamatan, perekaman, pencatatan. Teknik
\end{abstract}


analisis data dalam penelitian ini adalah mendeskripsikan hasil rekaman, reduksi data, interpretasi data, dan menarik kesimpulan. Berdasarkan hasil penelitian di SMA Warga Surakarta menunjukan bahwa, penggunaan tindak tutur direktif yang dilakukan oleh guru dan siswa lebih dominan adalah guru. Hal ini terjadi karena guru sebagai contoh yang baik dalam bertutur dan santun dalam berbahasa.

Kata kunci: tindak tutur direktif, pembelajaran bahasa Indonesia

\section{PENDAHULUAN}

Kegiatan dalam proses belajar mengajar di dalam kelas merupakan bentuk interaksi antara guru dan siswa. Interaksi yang yang terjadi secara tidak langsung untuk memahami satu dengan yang lain. Hal ini disampaikan oleh (Maslow dalam Slavin, 1994), bahwa interaksi yang dilakukan dalam proses pembelajaran untuk mengetahui kebutuhan fisiologi, keselamatan, cinta, dan harga diri sebagai kebutuhan dasar yang diberikan sebelum kebutuhan pertumbuhan.

Proses pembelajaran di dalam kelas, guru memiliki kewajiban untuk mengontrol siswa yang sedang menerima materi atau arahan yang disampaikan oleh guru. Siswa sebagai mitra tutur memiliki kedudukan yang rendah sehingga mudah diatur oleh guru. Hal ini senada dengan pendapat Stubbs (1983) yakni guru memiliki peran sebagai pengelola kelas, mengatur siapa, berapa, dan kapan siswa berbicara, mengatur jenis pertanyaan dengan memanfaatkan tindak tutur, khususnya tindak tutur ilokusi, guru dapat mengevaluasi jawaban yang disampaikan oleh siswa, dan memberikan umpan balik sesuai dengan pertanyaan yang disampaikan oleh siswa.

Konteks dalam proses pembelajaran guru memiliki peranan untuk menyampaikan fungsi-fungsi komunikasi yang berkaitan denngan pembelajaran di dalam kelas. Fokus kajian pada bagian ini adalah tuturan direktif yang menjadi unit fungsional dalam berkomunikasi. Tindak tutur direktif di lingkungan sekolah khsusnya dalam proses pembelajaran Bahasa Indonesia menjadi perhatian siswa dan guru. Tuturan yang disampaikan oleh guru dapat mempengaruhi lawan tutur yaitu siswa sebaliknya tuturan yang disampaikan oleh siswa mempengaruhi lawan tutur yakni guru. Tuturan yang disampaikan mengandung nilai kesantunan yang mempengaruhi kegiatan proses belajar mengajar di dalam kelas.

Permasalahan dalam penelitian ini dirumuskan sebagai berikut. Bagaimana tindak tutur direktif dalam pembelajaran Bahasa Indonesia di SMA Warga Surakarta? Tujuan dalam penelitian yang akan dicapai dalam penelitian ini yaitu untuk mengetahui tindak tutur direktif dalam pembelajaran Bahasa Indonesia di SMA Warga Surakarta.

Tindak tutur direktif sering digunakan oleh guru dalam proses pembelajaran. Tuturan yang disampaikan berupa tuturan ekspresi verba. Tujuan suatu tuturan yang disampaikan untuk mempengaruhi lawan tutur untuk bertindak sesuai dengan apa yang disampaikan oleh penutur. Penelitian tindak tutur direktif dan kesantunan berbahasa dilakukan oleh beberapa peneliti terdahulu yakni Qomariayah (2017), Sumarti (2015), Ardianto (2013), Alfih Iin (2014), Yuliarti (2015), Prayitno, H (2011), Astuti (2017), Safar (2016), dan Purwahida (2019). Dari beberapa peneliti terdahulu tersebut ditemukan bahwa tindak tutur direktif digunakan guru dan siswa pada tahap awal pembelajaran, inti pembelajaran dan akhir pembelajaran.

Pada tahap awal pembelajaran guru melakukan tuturan dengan cara memberikan 
salam, menyuruh para siswa untuk berdoa dan memeriksa kehadiran siswa. Tahap inti dalam pembelajaran guru menyampaikan materi dan memulai pembelajaran dan menyuruh siswa mengerjakan latihan soal. Pada tahapan terakhir guru meminta siswa untuk menyimpulkan pembelajaran yang sudah dilakukan dan memberi salam penutup. Berdasarkan tahapan yang disebutkan guru dan siswa menciptakan suasana pembelajaran yang efektif. Kegiatan belajar mengajar henghendaki implikatur logis sehingga proses pembelajaran berjalan dengan baik.

Proses belajar mengajar penggunaan tindak tutur oleh guru harus dilakukan secara efektif untuk mencapai tujuan pembelajaran yang maksimal. Hal ini berkaitan dengan tindak tutur direktif yang dilakukan oleh pengajar dalam proses pembelajaran karena kelas merupakan tempat dimana siswa mempraktekkan kemampuan diri berkaitan dengan kereampilan dan kemampuan berkomunikatif (Sinclair \& Brazil, 1982).

Penggunaan tindak tutur ilokusi dalam pembelajaran mengandung maksud dan daya tuturan. Tindak tutur ilokusi tidak mudah diidentifikasi (Purwahida, 2018), karena tindak tutur ilokusi berkaitan dengan siapa bertutur kepada siapa, kapan dan dimana tindak tutur itu dilakukan dan sebagainya. Tindak ilokusi ini merupakan bagian yang penting dalam memahami tindak tutur, (Wijana, 2005). Tindak ilokusi disebut sebagai The Act of Doing Something. Leech (dalam Rustono 1999) menjelaskan juga bahwa untuk mempermudah identifikasi ada beberapa verba yang menandai tindak tutur ilokusi, antara lain melaporkan, mengumumkan, bertanya, menyarankan, berterimah kasih, mengusulkan, mengakui, mengucapkan selamat, berjanji, mendesak, dan sebagainya. Lubis (dalam Wijana, 2005), memberikan defenisi lebih rinci dengan beberapa batasan mengenai tindak ilokusi yaitu pengucapan suatu pernyataan, tawaran, janji, pertanyaan, permintaan maaf, dan sebagainya. Ini erat hubungannya dengan bentuk-bentuk kalimat yang mengungkapkan suatu ungkapan (Setiawan, 2005), menambahkan bahwa tindak ilokusi adalah tindak bahasa yang didefenisikan dengan kalimat pelaku yang eksplisit. Tindak ilokusi merupakan tekanan atau kekuatan kehendak orang lain yang terungkap dengan kata-kata kerja: menyuruh, memaksa, mendikte kepada..., dan sebagainya.

Tindak tutur direktif disebut juga tindak tutur imposif, yaitu tindak tutur yang dilakukan oleh penuturnya dengan maksud agar lawan tuturnya melakukan tindakan yang disebutkan dalam ujaran itu. Tuturan yang termasuk dalam jenis tindak tutur ini antara lain tuturan memaksa, mengajak, meminta, menyuruh, menagih, mendesak, memohon, menyarankan, memerintah, memberikan aba-aba atau menantang. Contoh, "silakan tinggalkan kelas ini". Tuturan tersebut termasuk tuturan direktif karena tuturan tersebut dimaksudkan penuturnya agar mitra tutur melakukan tindakan yakni meninggalkan kelas.

\section{METODE PENELITIAN}

Jenis penelitian yang digunakan dalam penelitian ini adalah deskriptif kualitatif. Jenis penelitian ini disesuaikan dengan tujuan penelitian yakni mendeskripsikan, menganalisis tindak tutur direktif dan kesantunan berbahasa antara guru dengan siswa dan siswa dengan siswa khususnya dalam proses pembelajaran Bahasa Indonesia di SMA Warga Surakarta.

Subjek adalah pokok sasaran penelitian yang dilakukan oleh peneliti secara sistematis dalam memecahkan suatu persoalan. Peneliti menjadikan guru dan siswa 
sebagai subjek penelitian. Dalam penelitian bahasa, baik data maupun objek penelitian sama-sama merupakan satuan kebahasaan, perbedaannya adalah data merupakan satuan lingual yang berada pada tataran yang lebih tinggi dari pada objek penelitian diterjemahkan sebagai satuan kebahasaan yang dikhususkan untuk diteliti. Data tertentu merupakan satuan kebahasaan yang lebih besar, yang mengandung objek penelitian. Jadi objek dalam penelitian ini adalah tindak tutur direktif dan kesantunan berbahasa dalam proses pembelajaran Bahasa Indonesia.

Jenis data yang digunakan dalam dalam penelitian ini adalah data tulis berupa tuturan yang ada dalam proses pembelajaran Bahasa Indonesia. Arikunto (1998: 114) berpendapat bahwa sumber data dalam penelitian adalah subjek dari mana data diperoleh. Jenis data dalam penelitian ini adalah data tertulis. Data tertulis yang diperoleh dari hasil transkripsi tuturan dalam proses pembelajaran antara guru dengan siswa, siswa dengan siswa di SMA Warga Surakarta.

Pengumpulan data dalam penelitian ini dilakukan dengan teknik observasi nonpartisipasi, sehingga peneliti merekam tanpa melibatkan diri secara langsung dalam peristiwa tutur atau proses pembelajaran. 1) Teknik Simak Bebas Libat Cakap. 2) Dalam teknik ini, Penulis tidak dilibatkan langsung untuk ikut menentukan pembentukan dan pemunculan calon data kecuali hanya sebagai pemerhati-pemerhati terhadap calon data yang terbentuk dan muncul dari peristiwa kebahasaan yang berada di luar dirinya, (Sudaryanto, 1983). Data yang dibaca dengan teknik ini dapat berupa data dari sumber tertulis. Dalam penelitian ini, Penulis mengumpulkan data dari beberapa peristiwa adegan tuturan dalam proses pembelajaran tersebut. 3) Teknik Sadap. Pengumpulan data dengan teknik ini adalah pelaksanaan metode simak dengan menyadap penggunaan bahasa seseorang atau beberapa orang. Penggunaan bahasa yang disadap dapat berbentuk tulisan. 4) Teknik kopi dan teknik catat. Teknik kopi dilakukan untuk mengambil data dengan melakukan kopi tuturan perkacapan yang terdapat dalam proses pembelajaran terssebut.Teknik catat adalah teknik yang dilakukan untuk mencatat penggalan tuturan percakapan dalam hasil rekaman.

Kesuma (2007) menyebutkan beberapa langkah yang diambil untuk menganalisis data dalam penelitian, yaitu penyeleksian data, pengklasifikasian data, dan penganalisisan data. Data yang dikumpulkan dianalisis berdasarkan hasil seleksi dan dikaji seluruhnya. Data yang diklasifikasikan berdasarkan masalah penelitian. Analisis data menggunakan metode deskripsi kualitatif.

Peneliti akan menyajikan hasil analisis data, dalam penelitian ini peneliti menggunakan teknik informal. Teknik informal adalah teknik menyajikan hasil analisis data menggunakan kata-kata biasa, sesusai dengan pendapat Sudaryanto, (1993: 145). Jadi, peneliti akan menyajikan hasil analisis data penelitian ini menggunakan kata-kata biasa. Waktu yang digunakan dalam penelitian ini mulai dari tanggal 1 sampai dengan tanggal 7 Oktober 2019. SMA Warga Surakarta. Lokasi dalam penelitian ini adalah SMA Warga Surakarta meliputi kelas XI IPA II, XI IPS I, dan XII IPA.

\section{HASIL DAN PEMBAHASAN}

Hasil penelitian dan pembahasan tentang tindak tutur direktif dalam pembelajaran Bahasa Indonesia di SMA Warga Surakarta sebagai berikut. Tindak tutur direktif yang digunakan guru dan siswa dalam proses pembelajaran di SMA Warga Surakarta meliputi 1) memaksa, 2) mengajak, 3) meminta, 4) menyuruh, 5) menagih, 6) memohon, 7) menyarankan, 8) memerintah. 


\section{Tindak Tutur Memaksa}

Kata memaksa secara leksikal kata memaksa diartikan sebagai mengerjakan sesuatu yang diharuskan walaupun tidak mau. Sedangkan kata memaksa memiliki makna semantik tuturan yang disampaikan kepada lawan tutur untuk mengikuti suruhan.

Data 1: Setiap pertanyaan harus dijawab.

Konteks dalam tuturan ini adalah tuturan dituturkan kepada mitra tutur yakni untuk mempertanggungjawabkan apa yang disampaikan dalam kegiatan diskusi. Tuturan ini dituturkan oleh guru kepada siswa dalam proses pembelajaran.

Berdasarkan data (01) di atas yang merupakan tindak tutur memaksa karena penutur menuturkaln kata harus. Pilihan kata harus oleh penutur agar apa yang disampaikan dilakukan tanpa ada alasan tertentu. Jadi berdasarkan kaliamt Setiap pertanyaan harus dijawab merupakan kalimat yang disampaikan guru kepada lawan tutur atau mitra tutur yaitu siswa kelas XI IPS I untuk melakukan apa yang disampaikan oleh penutur yakni bapak supryanto sebagai guru mata pelajaran bahasa Indonesia. Kalimat ini dituturkan dalam proses pembelajaran yakni berdiskusi. Penutur juga mengharuskan apa yang ditanyakan dalam proses diskusi harus dijawab.

\section{Tindak Tutur Mengajak}

Kata mengajak secara leksikal diartikan sebagai meminta atau menyilakan, menyuruh. Sedangkan kata meminta atau mengajak secara semantik memiliki makna permintaan kepada mitra tutur. Tuturan yang disampaikan penutur kepada lawan tutur dengan maksud lawan tutur mengikuti apa yang disampaikan.

Data 2: Ayo, sekarang mulai kerjakan pendahuluan dan latar belakang

Konteks tuturan di atas dituturkan untuk mengajak lawan tutur yakni para siswa untuk mengerjakan tugas yang diberikan oleh guru. Konteks dalam tuturan ini berkaitan dengan proses pembelajaran Bahasa Indonesia di kelas XI IPS I.

Berdasarkan data 2 di atas dikatakan tindak tutur mengajak karena pada awal kalimat tersebut ada ajakan berupa kata "ayo". Pada kalimat "Ayo, sekarang mulai kerjakan pendahuluan dan latar belakang" merupakan tuturan yang disampaikan kepada lawan tutur yakni siswa untuk mengerjakan makalah yang diberikan oleh mitra tutur yang berprofesi sebagai guru bahasa Indonesia. Dalam tuturan ini penutur menginginkan apa yang disampaikan dapat dilakukan dengan baik.

\section{Tindak Tutur Meminta}

Kata meminta secara leksikal diartikan sebagai berkata-kata supaya diberi atau mendapat sesuatu. Sedangkan kata meminta secara semantik memiliki makna permintaan kepada mitra tutur. Tuturan yang disampaikan penutur kepada lawan tutur dengan maksud tertentu. Misalnya tindak tutur guru dalam proses pembelajaran di SMA Warga Surakarta.

Data 3. Tolong dengar sini.

Konteks yang terjadi dalam tuturan ini adalah Guru meminta agar siswa memperhatikan penjelasan yang disampaikan. Tuturan di atas dituturkan pada saat proses pembelajaran di kelas XI IPS I. Tuturan ini memiliki makna bahwa dalam proses 
pembelajaran keadaan kelas tidak kondutif oleh karena itu guru menuturkan tuturan "tolong dengar sini" untuk mengendalikan keadaan kelas yang ribut.

Berdasarkan data 3 di atas tuturan "Tolong dengar sini" dituturkan oleh bapak supryanto sebagai guru bahasa Indonesia dalam proses pembelajaran meminta siswa untuk memperhatikan apa yang disampaikan. Permintaan yang disampaikan oleh penutur memiliki maksud agar pesan yang disampaikan diterima dengan baik. Tuturan ini dituturkan karena suasana kelas yang ramai sehingga menyulitkan penutur untuk menyampaikan pesan yang akan disampaikan.

\section{Tindak Tutur Menyuruh}

Kata menyuruh secara leksikal diartikan sebagai perintah supaya melaukan sesuatu. Sedangkan secara semantik kata menyuruh memiliki makna sebagai menyuruh untuk melakukan tindakan seperti yang dituturkan. Tuturan menyuruh disampaikan guru kepada siswa untuk mengerjakan sesuatu.

Data 4: Sekarang kerjakan latar belakang dan rumusan masalah.

Konteks yang terjadi dalam tuturan ini adalah tuturan guru dalam proses pembelajaran untuk mengerjakan makalah yang diberikan. Tuturan ini memiliki daya untuk lawan tutur melakukan apa yang inginkan penuutur.

Tuturan yang disampaikan oleh penutur pada data 4 diatas memiliki daya tindak tutur menyuruh. Hal ini ditandai dengan kata "kerjakan" pada kalimat "Sekarang kerjakan latar belakang dan rumusan masalah". Tujuan tuturan ini dituturkan agar mitra tutur melakukan apa yang diinginkan penutur yang mengerjakan latar belakang dan rumusan masalah dalam makalah tersebut. Bapak supryanto sebagai penutur menyuruh mitra tutur yakni siswa kelas XI IPS I untuk melakukan apa yang disampaikan.

\section{Tindak Tutur Menagih}

Kata menagih secara leksikal diartikan sebagai bentuk meminta atau memperingatkan, mendesak supaya membayar. Sedangkan secara semantik tuturan menagih memiliki makna bahwa apa yang disepakati perlu adanya kesadaran untuk menepati. Tuturan menagih memperlihatkan adanya hubungan antara penutur dan lawan tutur.

Data 5. Dimana tugas kelompok kalian karena pak mau lihat.

Konteks: tuturan ini dituturkan ketika guru sebagai penutur yang menagih tugas yang diberikan. Siswa kelas XII IPA sebagai lawan tutur yang berada di dalam kelas dan ingin memulai pembelajaran namun sebelum memulai pembelajaran guru menagih tugas kelompok yang ditugaskan minggu yang lalu.

Berdasarkan data 5 diatas penutur menagih tugas yang diberikan minggu yang lalu untuk dikumpulkan. Tuturan ini disampaikan agar mitra tutur melakukan apa yang disampaikan oleh mitra tutur yakni memperliharkan atau mengumpulkan pekerjaan rumah yang dilakukan oleh mitra tutur yakni siswa kelas XII IPA. Penutur menutur kan tuturan ini dengan maksud lain yaitu ingin mengetahui siapa saja yang tidak mengerjakan tugas yang diberikan oleh penutur. 


\section{Tindak Tutur Memohon}

Kata memohon secara leksikal memilki arti minta dengan hormat, berharap supaya mendapatkan sesuatu. Sedangkan secara semantik kata memohon memiliki makna bahwa upaya untuk meminta atau mengelabui lawan tutur untuk melakukan apa yang diinginkan.

Data 6. Pak sangat memohon supaya jaga ketenangan dalam proses diskusi.

Konteks dalam tuturan ini adalah guru memohon agar siswa menjaga ketenangan dalam proses diskusi. Diskusi yang baik adalah ada pembicara dan ada pendengar.

Berdasarkan data 6 di atas tuturan "Pak sangat memohon supaya jaga ketenangan dalam proses diskusi" merupakan tindak tutur memohon karena ditandai dengan kata "memohon". Tujuan tuturan ini dituturkan agar siswa menjaga ketengan dalam diskusi. Bapak supryanto sebagai penutur merupakan guru yang sedang melaksanakan tugas yaitu mengajar dengan menggunakan metode pembelajaran yakni diskusi. Mitra tutur dalam pembelajaran ini adalah siswa kelas XI IPA II.

\section{Tindak Tutur Menyarankan}

Kata menyarankan secara leksikal diartikan sebagai pendapat atau usulan, anjuran, cita-cita yang dikemukakan untuk dipertimbangkan. Sedangkan secara semantik kata menyarankan memiliki makna sebagai usulan yang diberikan penutur kepada lawan tutur untuk mempertimbangkan maksud yang disampaikan oleh penutur.

Data 7: Tadi Mas Irfan membaca kurang jelas, sehingga keadaan menjadi rancau. Oleh karena itu perlu memperbaiki cara membaca

Konteks yang terjadi dalam tuturan ini adalah proses diskusi dalam pembelajaran bahasa Indonesia. Salah satu memberikan saran kepada lawan tutur tengtang ketidakjelasan suara dalam penyampaian materi.

Berdasarkan data 7 diatas penutur menyampaikan saran kepada lawan tutur terkait dengan penyampaian materi yang tidak jelas akibat dari suara dan teknik membaca yang kurang tepat. Penyampaian materi dalam diskusi membutuhkan kejelasan suara dan teknik membaca yang baik yaitu memperhatikan tanda baca. Tuturan "Tadi Mas Irfan membaca kurang jelas, sehingga keadaan menjadi rancau. Oleh karena itu perlu memperbaiki cara membaca" dikategorikan dalam tindak tutur menyarankan karena dalam tersebut adanya penanda "perlu memperbaiki cara membaca".tuturan ini dituturkan oleh siswa kelas XI IPA II.

\section{Tindak Tutur Memerintah}

Kata memerintah secara leksikal memiliki arti perkataan yang bermaksud menyuruh melakukan sesuatu. Sedangkan secara semantik kata memerintah memiliki makna bahwa usaha untuk mengelabui lawan tutur untuk bertindak sesuai dengan acuan yang diberikan. Misalnya

Data 8: Setelah kerjakan rumusan masalah setiap kelompok mempresentasi di depan.

Konteks yang terganbar dalam tuturan ini adalah penutur menyampaikan kepada lawan tutur yakni para murid untuk menyampaikan hasil kerja kelompok di dalam kelas. Proses pembelajaran guru memerintahkan mitra tutur yakni siswa untuk melakukan apa yang disampaikan yakni mempresentasikan tugas yang diberikan oleh guru atau mitra 
tutur.

Berdasarkan data 8 di atas, tuturan "Setelah kerjakan rumusan masalah setiap kelompok mempresentasi di depan" merupakan tuturan memrintah karena penutur menggunakan kalimat perintah dalam menyampaikan maksud dan tujuannya. Tujuan yang ingin dicapai dalam tuturan ini adalah siswa melakukan apa yang dituturkan yakni mempresentasikan tugas yang diberikan. Tuturan ini disampaikan oleh guru sebagai penutur dan lawan tutur adalah siswa kelas XI IPA II.

Berdasarka hasil temuan dan deskripsi di atas, terdapat beberapa interpretasi tindak tutur direktif yakni tindak tutur memaksa, tinak tutur mengajak, tindak tutur meminta, tindak tutur menyuruh, tindak tutur menagih, tindak tutur memohon, tindak tutur menyarankan, dan tindak tutur memerintah dalam proses pembelajaran yang terjadi di kelas XII IPA, XI IPA II, XI IPS I.

Berdasarkan hasil pengamatan tentang pembelajaran Bahasa Indonesia di SMA Warga Surakarta selalu memberikan ruang kepada siswa untuk menyampaika pendapat dan segala keluhan berkaitan dengan pelajaran dan masalah pribadi. Kesempatan untuk berbicara yang diberikan guru terhadap siswa bertujuan untuk mengetahui permasalahan yang dialami setiap siswa yang memiliki masalah dengan menyampaikan masalah tersebut dengan menggunakan bahasa yang baik dan benar. Hal ini disampaikan oleh bapak Supriyanto sebagai guru bahasa Indonesia di SMA Warga Surakarta.

Berdasarkan hasil wawancara dengan ibu Fatma sebagai guru Bahasa Indonesia sebagai berikut: Menurut anda apakah penggunaan bahasa yang berkaitan dengan tindak tutur sudah dikatakan baik pada tingkat menengah atas?

"Menurut pendapat saya, penggunaan bahasa dalam percakapan sudah dikatakan baik karena sudah memperhatikan siapa lawan bicara dan penggunaan diksi yang baik dalam berkomunikasi. Komunikasi yang terjadi di sekolah selama ini tidak ada penyimpangan berkaitan dengan komunikasi dengan guru tapi komunikasi antara siswa dengan siswa masih mengalami penyimpangan. Hal ini terjadi karena komunikasi yang dilakukan antara teman sebaya (Fatma, 20 Oktober 2019).

Dari kutipan di atas membuktikan bahwa penggunaan bahasa dalam berkomunikasi siswa sudah membedakan siapa lawan tutur. Siswa dapat memperhatikan tuturan dalam berkomunikasi misalnya mengajukan permintaan, mengajukan permohonan dan lain sebagainya. Pada tingkatan sekolah menengah atas siswa sudah membedakan siapa lawan bicara.

Berdasarkan hasil analisis data, tindak tutur direktif dalam pembelajaran di SMA Warga Surakarta didominasi oleh tindak tutur yang dilakukan oleh guru sebagai berikut.

a. Setiap pertanyaan harus dijawab.

b. Setiap pertanyaan harus dijawab.

c. Tolong dengar sini.

d. Sekarang kerjakan latar belakang dan rumusan masalah.

e. Dimana tugas kelompok kalian karena pak mau lihat.

f. Pak sangat mengharapkan supaya jaga ketenangan dalam proses diskusi.

g. Setelah kerjakan rumusan masalah setiap kelompok mempresentasi di depan. 


\section{KESIMPULAN}

Berdasakan hasil penelitian ditemukan tindak tutur direktif dalam proses pembelajaran Bahasa Indonesia di SMA Warga Surakarta meliputi tindak tutur 1) memaksa, 2) mengajak, 3) meminta, 4) menyuruh, 5) menagih, 6) memohon, 7) menyarankan, 8) memerintah. Fungsi tindak tutur dalam proses pembelajaran diekspresikan secara langsung oleh guru. Tuturan antara guru dan siswa memiliki peranan pemting dalam proses pembelajaran. Jika hubungan antara siswa dan guru terjalin dengan baik, maka tuturan dalam proses komunikasi berjalan dengan baik.

\section{UCAPAN TERIMA KASIH}

Peneliti menyampaikan ucapan terima kasih kepada pembimbing 1: Prof. Dr. Sarwiji Suwandi, M.Pd. dan pembimbing 2: Dr. Nugraheni Eko Wardani, M.Hum. yang telah memberikan waktu dan tenaga dalam proses penyelesaian artikel ini. Ucapan terima kasih juga disampaikan kepada kedua orang tua dan teman-teman seperjuangan program pascasarjana pendidikan bahasa Indonesia UNS yang telah memberikan semangat dan motivasi penyelesaian artikel ini, dan tim redaksi Aksis: Jurnal Pendidikan Bahasa dan Sastra Indonesia atas saran dan masukan untuk perbaikan penulisan artikel ini.

\section{REFERENSI}

Alviah, I. (2014). Kesantunan Berbahasa dalam Tuturan Novel Para Priyayi Karya Umar Kayam. Jurnal Seloka Pendidikan Bahasa dan Sastra Indonesia Volume 3 (2), $2301-6744$.

Ardianto. (2013). Tindak Tutur Direktif Guru dalam Wacana Interaksi Kelas Anak Tunarungu.. Jurnal Penelitian Bahasa, Sastra, dan Pengajaran Volume 12, (1) 112.

Arikunto, S. (1998). Prosedur Penelitian Suatu Pendekatan Praktek. Jakarta: Rineka Cipta.

Astuti, M. Putry., Widodo H.S., Sunoto. (2017). Kesantunan Tuturan Direktif dalam Interaksi Pembelajaran di SMA. Jurnal Pendidikan UM Volume 2 (3) 434-439.

Hafizah. (2019). Politeness Strategy in Students Lingua to Their Lecturers via WhatsApp at in Information Technology Department of Technical Faculty Universitas Bhayangkara Jakarta Raya. Aksis: Jurnal Pendidikan Bahasa dan Sastra Indonesia 3(2). 424-433. doi: doi.org/10.21009/AKSIS.020108

Huda, M., \& Purwahida, R. (2013). Keruntutan Alur dalam Pembelajaran Menulis Melalui Teknik Recount.

Kusuma. (2007). Metodelogi Penelitian Kualitatif dan Kuantitatif. Jakarta: Gramedia.

Leech, G. (1983). Prinsip-prinsip Pragmatik (Diterjemahkan oleh Oka). Jakarta: Balai Pustaka. 
Maslow, I. H. (1994). Motivasi dan Kepribadian. PT PBP: Jakarta.

Purwahida, R. (2018). Problematika Pengembangan Modul Pembelajaran Baca Tulis Anak Usia Sekolah Dasar. Aksis: Jurnal Pendidikan Bahasa dan Sastra Indonesia 2(1). 118-134. doi: doi.org/10.21009/AKSIS.020108

Purwahida, R. (2019, September). Teacher's Understanding of Hybrid Learning Design. In Journal International Seminar on Languages, Literature, Arts, and Education (ISLLAE) (Vol. 1, No. 2, pp. 265-267).

Puspitasari, M., Andayani, \& Suwandi, S. (2019). The Role of Student's Language Competence for Producing Negotiation Text. Aksis: Jurnal Pendidikan Bahasa dan Sastra Indonesia 3(2). 371-377. doi: doi.org/10.21009/AKSIS.020108

Prayitno, H. J. (2011). Teknik dan Strategi Kesantunan Direktif di Kalangan Andik SD Berlatar Belakang Budaya Jawa. Jurnal UMS Kajian Linguistik dan Sastra, Volume 23 (2) 204-218.

Prayitno, H. J. (2009). Perilaku Tindak Tutur Berbahasa Pemimpin dalam Wacana Rapat Dinas . Jurnal UMS Kajian Linguistik dan Sastra, Volume 21 (2) 132-146.

Qomariyah, L. ( 2017). Tindak Tutur Direktif (TTD) Guru dalam Pembelajaran Bahasa Arab. Journal of Arabic Studies Volume 2 (1) 1-18.

Rahadini, A. Ajeng., S. (2014). Kesantunan Berbahasa dalam Interaksi Pembelajaran Bahasa Jawa. Jurnal LingTera Volume 1 (2) 136-144.

Safar, Muh. (2016). Tindak Tutur Direktif dalam Transaksi Jual Beli Di Pasar Sentral Watampone. Jurnal Humanus Volume 15 (2) 167-176.

Sinclair, J. Mc. \& Brazil, D. (1982). Teacher Talk. Oxford: Oxford University Press.

Stabbs, M. (1983). Discaurse Analisys, The Socioliguistic Analisys of Natural Language. Oxford: Basil Balckwell.

Sudaryanto. (1993). Metode dan Aneka Teknik Analisis Bahasa. Yogyakarta: Duta Wacana University Press.

Sumarti. (2012). Strategi Tindak Tutur Direktif Guru dan Responswara Afektif Siswa. Jurnal Litera FKIP Universitas Lampung Volume 4 (2) 79-85.

Yuliarti, Rustono, \& Nuryatin, A. (2015). Tindak Tutur Direktif dalam Wacana Novel Trilogi Karya Agustinus Wibowo. Jurnal Litera FKIP Universitas Lampung Volume 4 (2) 110-129.

Wijana, J. (1996). Dasar-Dasar Pragmatik. Yogyakarta: Penerbit Andi. 